gesellschaft, and invitations sent to pilots of the German Air Force and to the leading German archæologists. The exhibition also included a selection of photographs taken by German pilots, who are now keenly interested in the subject and have begun to collaborate with the archæologists. It would appear that the exhibition, which lasted for two days, and of which the proceedings were devoted to the discussion of technical problems, was a great success. The meeting closed with a lecture by Mr. Crawford, when Dr. Buttler and Ministerialrat Ewald were present and also spoke. To this lecture members of the public were admitted, and several hundreds of people were present. An account of the proceedings is to be published by Lufthansa as an illustrated monograph.

AT the conclusion of the meeting, Mr. Crawford, in proceeding by air to Athens on business connected with the Greek portion of the map of the Roman Empire, was able to make a number of interesting observations. On his way to Berlin he had observed traces of an early, probably medieval, field system between Brussels and Cologne, of which he had also detected indications on some of the German air photographs. Similar evidence was obtained in the soil marks-long white bands forming a patternbetween Budapest and Belgrade. These, in his opinion, are the vestiges of an ancient field system. Whatever their age and original intent, they seem to have no relation to the existing field system, which itself has the appearance of considerable antiquity. To decide the point, a large area should be photographed from the air in suitable conditions, and a mosaic constructed, with subsequent excavation at selected points to decide the matter. In addition, Mr. Crawford observed three Roman camps on arable land, and the course of several defensive dykes, some of post-Roman date, which though long known to exist, have never been properly investigated. Mr. Crawford concludes by pointing out that this region is one of the best fields in Europe for combined fieldwork from the air and on the ground, and expresses the hope that our archæological colleagues of Yugoslavia will follow the example of Germany and inaugurate work in this unexplored and most promising field.

\section{Excavations in the Egyptian Sudan, r937-8}

THE annual exhibition of the Egypt Exploration Society opened at the Society's rooms, 2 Hinde Street, Manchester Square, London, W.1, on June 23. It will remain open daily until July 14. In 1937-38 excavation was continued on the site of the fortresstown of Sesebi on the banks of the Nile, about one hundred and eighty miles south of Wady Halfa. Shortly before the close of the season, the site had been completely excavated, and the expedition spent twelve days in a preliminary examination of the new concession at Amarah West, about sixty miles north of Sesebi, where it is hoped to begin systematic excavation in 1938-39. Although the number of finds at Sesebi this year was small, they are of no little archæological and historical interest. Faience objects bearing the name of Amenhotep IV from intact foundation deposits under the walls of the town indicate that the town, as well as the temple, was built by this king about 1480 B.c., before he adopted Aten worship and changed his name to Akhenaten. A sandstone block bearing a representation of the god Amun, or of Amenhotep wearing the plumes of the god, which was found built upside down in the sanctuary of the temple erected by Seti $\mathbf{I}$, is of no less interest as an example of the art of the period before Akhenaten changed the canons of art, as well as his religion. Both these finds are of importance as belonging to a period from which material is scanty. A black granite fragment showing a daughter of the king, embraced by a sister or a parent, is the only clearly Amarna piece that has been discovered at Sesebi. An interesting sandstone bust of a dead man, swathed in mummy bands, which when in position would appear to be bursting from the ground, is a rare example of a symbol of resurrection.

THE most interesting and significant fact which emerges from the excavation at Sesebi is that though built in the conventional form of a fortress-town, it had no moat, no special defences for its gates, and there was, apparently, no strategic reason for its position. It could not withstand a prolonged attack, whereas other previously known fortress towns of this region command strategic points on the Sudanese trade routes, have deep moats, and are strongly fortified. Hence it would appear that by the time Sesebi was built, the political and economic dominance of the Egyptian Empire in the Sudan was sufficiently firmly established to make the establishment of fortress-towns like Sesebi as anything more than trade and religious centres superfluous-an important piece of evidence of the organization of the Egyptian Empire in the Eighteenth and Nineteenth Dynasties. At Amarah West there has come to light in the preliminary tests evidence which suggests that there may have been a late Eighteenth Dynasty occupation as well as that of the Nineteenth, of which the remains, in the form of temple and town, crown the mound of the site under a deposit of some six feet of blown sand. This deposit has kept the walls in an excellent state of preservation, to a height of six feet, and holds out promise of inscriptional material, and possibly statuary, in the temple. An interesting find, of which it is hoped more will be heard in future excavation, is an axe-celt and two agate arrow-heads, which appear to afford evidence here of a new and little-known Sudanese culture.

\section{Exhibition of History of Handwriting}

As exhibition now open at the London County Council's Horniman Museum, Forest Hill, London, S.E., illustrates the development of handwriting and its different systems. It begins with pictographic and hieroglyphic forms, and shows how the conventionalized breaking down of the picture produced the alphabetic systems, tracing the development through early Phœnician to Greek and Latin. The development of Babylonian cuneiform is also shown, demon. strating how its character was determined by the 
nature of the material used for record, the clay tablet, which necessitated the use of a stylus in the form of a stamp lending itself to ready and relatively rapid duplication. Among later developments shown are the Lombardic, Merovingian, Visigothic, AngloSaxon and Irish 'hands', as well as the still later and contrasting forms of Italian and English SecretaryShakespeare's signature is an example of the latterbetween which rivalry lasted in England until well into the seventeenth century. The exhibits include illuminated manuscripts, samplers and tally sticks, facsimiles of important historical documents, such as Magna Charta, and of the signatures of prominent personages, ancient and modern. The exhibition will remain open until August 31 .

\section{"Druid" Temple near Glasgow}

A LARGE part of this temple on the AnnieslandDuntocher Boulevard at Glasgow, near Clydebank and Kilbowie, has now been re-constructed. New wood has been substituted for the decayed and carbonized original timber. The circular area of the sanctuary appears to have a diameter of 245 feet, bounded probably by a ring of nineteen large, white, hard sandstone pillars equidistantly set and each about 8 feet in height. Numerous graves have been found under the floor or old surface. As indicated by the pottery and other relics, the burials near the centre are of the Stone Age. The outer graves belong to later prehistoric periods, the various phases of the Bronze Age. The temple was evidently a favourite place for interments for a very long period. Four graves, very close to the centre of the temple, have just been opened and may be inspected during the next few days, after which they will be again covered over. These four graves are all built of large stones and in two cases contain much decayed timber and wickerwork. The topmost stones in several cases bear curious devices belonging to the class of carvings known as 'cups-and-rings'. Stone implements were found in some of the tombs. The largest of the four tombs has a depth of 8 feet. The walling of its shaft contains about fifty stones. The excavation of this site has been carried out by Mr. Ludovic Mann, 183 West George Street, Glasgow, C.2.

\section{New Pathological Institute at Guy's}

THE new Pathological Institute of Guy's Hospital Medical School was opened on June 23, by the chancellor of the University of London, the Earl of Athlone, supported by the vice-chancellor, Sir Robert Pickard, and the principal, Dr. H. L. Eason. The Governing Body was represented by Viscount Goschen, Viscount Nuffield, Lord Cunliffe, and Mr. R. C. Nesbitt. The building is a large eight-story fireproof extension behind the present anatomy, physiology and chemistry departments on a site formerly occupied by Spur Inn Yard, the outbuildings of a famous medieval Southwark inn. It combines in a single unit the former scattered laboratories of pathology, clinical chemistry and bacteriology, originally housed in old adapted warehouses. Ample laboratory accommodation is also provided for the Clinical Research Unit recently established by the
Medical Research Council at Guy's and for the Guy's Hospital clinical research fellow. The connexion between the Medical School and the Hospital will be fully maintained by the provision of extensive accommodation for the hospital routine investigations. Thirty fully equipped laboratories have been provided for original investigations. The total cost of the building and equipment has been between $£ 85,000$ and $£ 90,000$, of which $£ 10,000$ has been contributed in the form of a capital grant by the University Court. There remains a debt of some $£ 40,000$, which, until paid off, will prevent the full realization of the objects for which the building has been provided.

\section{The Newcomen Society}

Favoured with beautiful weather, the Newcomen Society held its summer meeting in the Lake District on June 15-18. The programme was a very full one and included visits to mines, iron furnaces, snuff mills, an organ building works, a bobbin mill, a paper mill and Kendal Museum. At Lindale-in-Cartmel a short stay was made to inspect the cast-iron obelisk to the memory of the great iron-master John Wilkinson, and in a small engineering shop near Kendal the members found a very early iron planing machine, which it is to be hoped will one day find a place in a museum, instead of passing to the scrap-heap. With its many streams, the Lake District abounds in turbines and water-wheels, several of which are of considerable interest. Not the least interesting items in the programme were the visits to the Greenside Lead Mines, Glenridding, which, after being worked for two hundred years, are being modernized, and to the old copper mine at Goldscope, a short way from Keswick, which was worked in the days of Queen Elizabeth by the Society for the Mines Royal. At a meeting on the evening of June 15, a paper was read on the works at Goldscope, by Mr. Rhys Jenkins, who has traced the immigration into the district of some 150-200 German miners from the Tyrol. The principal figure in the venture was Daniel Hochstether, while much of the capital was provided by the Augsburg firm, Haug and Co., the account books of which are still preserved.

\section{The Dartmoor Catchments}

Among the papers presented at the annual general meeting of the British Waterworks Association on June 22 were two containing certain features of general scientific interest. The paper on "The Dartmoor Catchments" by Mr. Hansford Worth gave a detailed description of the physical features of the great granite highland occupying an area of 248 square miles in the county of Devon. He divided it into three districts, the eastern, the northern and the southern, according to differences of elevation. $\mathrm{He}$ explained how the weathering of the granite results in a product, locally known as 'Growan'. Owing to the softening of the rock and the loss of its coherence as the result of the decay of the felspars, there is evolved a sandy, and not a clayey mass, which, near the surface, shows the movement known as 'hillcreep', an excellent example of which is to be seen 